DOI 10.15393/j9.art.2016.3764

УДК 821.161.1.09"1917/1992"

\title{
Анна Евгеньевна Струкова
}

Петрозаводский государственный университет (Петрозаводск, Российская Федеращия) annaneyolova@yandex.ru

\author{
ДЕТСКАЯ УТОПИЯ \\ (повесть-сказка Э. Успенского \\ «Дядя Федор, пес и кот»)
}

Аннотация. Статья посвящена анализу специфики «детской» утопии на примере повести-сказки Э. Успенского «Дядя Федор, пес и кот», содержание которой и составляет собой детская мечта о хорошей жизни, peaлизации сокровенных детских желаний. Анализ ведется в сравнении с особенностями классической «взрослой» утопии. Отмечается фольклорно-сказочный характер детской утопии Э. Успенского, «сверхпроводимость» ее пространства; роль игры в ней; отсутствие, например, постоянной черты классической утопии - безгеройности. Делается, среди прочих, вывод о том, что социальная структура общества, главная во взрослой утопии, заменяется в анализируемой повести знакомым ребенку течением повседневного быта, который организует бытие. Особое внимание в статье уделяется полному символического смысла эпизоду с солнцем, которое героям подарили ученые Института физики Солнца. В сказочной повести Э. Успенского «Дядя Федор, пес и кот» взрослый и детский смыслы существуют не по отдельности, не сами по себе, а взаимодействуют, проникают друг в друга.

Ключевые слова: Э. Успенский, утопия, детская утопия, игра, литературная сказка, детская литература

B

творчестве Э. Успенского, одного из лучших (если не лучшего) писателя-сказочника второй половины XX века, повесть-сказка «Дядя Федор, пес и кот» занимает, пожалуй, центральное место. Ее персонажи - серьезный, любящий зверей мальчик дядя Федор, простодушный пес Шарик, «из простых собак, не из породистых» ${ }^{1}$, хозяйственный кот Матроскин - давно уже полюбились и маленьким, и большим читателям (как, впрочем, и сама деревня Простоквашино, где нашли себе дом герои), более того, шагнули, так сказать, со страниц сказки в реальность, зажили собственной жизнью. 
Детская утопия (повесть-сказка Э. Успенского «Дядя Федор, пес и кот») 263

Первое и общее впечатление от этой повести-сказки Э. Успенского - перед нами утопия, причем утопия детская. Размышляя над смыслом слова «утопия», Т. А. Чернышева справедливо замечает: «И что бы ни имел в виду Т. Мор, и как бы ни изощрялись в трактовке этого слова специалисты, с этим понятием прочно срослось представление о некоем идеале, мечте (“хорошее место”), но мечте нереальной, неосуществимой, почти фикции (“место, которого нет”). Недаром в бытовом словоупотреблении слово утопия соотносится с понятиями “миф” и “сказка”» $[6,304]$.

Именно мечта о хорошей жизни, представляющая собой реализацию сокровенных детских желаний (стать «взрослым», причем, «взрослым» по-детски, делать то, что интересно, чувствовать гармонию мира - хотя ребенок этих слов пока не знает, но уют, любовь и нежность он прекрасно чувствует), и составляет собой содержание повести-сказки Э. Успенского. «Деревня красивая. Кругом лес, поля и речка недалеко. Ветер дует такой теплый, и комаров нет» (405). Одновременно Простоквашино - это не только «хорошее место», но и «место, которого нет», ибо не бывает деревни без комаров, а коты и собаки не говорят (и ребенок это знает) на человеческом языке. Мир Простоквашино - это мир не только утопический, но и сказочный.

Чем же отличается «взрослая» утопия от «детской»?

Главной приметой классической «взрослой» утопии служит, как известно, изображение некоего, в той или иной степени совершенного, социального устройства общества. «Главным в утопии является... поиск такого устройства общественного бытия, при котором достигается счастье или, по крайней мере, благоденствие всех членов общества» [6, 306-307]. По замечанию составителя антологии утопической литературы В. А. Чаликовой, «утопия - это подробное и последовательное описание воображаемого... общества, построенного на основе альтернативной социально-исторической гипотезы» $[5,8]$.

Естественно, в детской утопии такого «подробного и последовательного» изображения социального устройства общества нет и не может быть. А если оно и появляется, то лишь сугубо во «взрослом» плане содержания текста, который не 
заметит (и не должен заметить) ребенок. Так, например, взрослый читатель второй части трилогии Н. Носова о приключениях Незнайки «без труда угадает <..> в названии переформулированное “Город Солнца". Перекличка с утопией Томаса Кампанеллы здесь очевидна. Ведь перед читателем не просто город технократического будущего, а модель общественного устройства» $[4,241]$.

У Э. Успенского взрослый и детский смыслы повести существуют не по отдельности, не сами по себе, как у Н. Носова, а взаимодействуют, проникают друг в друга.

Бросается в глаза, что в повести-сказке «Дядя Федор, пес и кот» социальной организации общества как бы и не существует. Нет «представителей власти»; не нужна прописка на новом месте жительства; дом достается героям совершенно бесплатно, они его просто выбрали: «- Сейчас будем дом выбирать. <...> Осмотрели они дом и обрадовались. Все в доме было. И печка, и кровати, и занавесочки на окнах! И радио, и телевизор в углу <..> И в огороде все было посажено... а в сарае удочка была» $(407,408)$; после ухода сына из дома мама и папа дяди Федора не обращаются в соответствующие органы, а лишь, поступая, так сказать, частным образом, дают объявление в газету. Отсутствие сведений о социальной структуре мира, где живут герои, не случайно - ведь и читатель-ребенок не имеет (и не желает иметь) эти сведения, они ему пока ни к чему. Изображение социальной структуры заменяется у Э. Успенского рассказом, точнее, показом прочности каждодневных форм быта, хорошо знакомых ребенку. Эти формы организуют жизнь героев и в городе, и в Простоквашино. Повседневные хлопоты, задушевные разговоры, споры кота и пса, письмо родителям, - все представляется незыблемым, как восход и заход солнца.

Социальная структура общества, главная во взрослой утопии, заменяется знакомым ребенку течением повседневного быта, который организует бытие, а иногда поднимается до его высот: «- И я тоже нормально жил. Серединка на половинку, - говорит дядя Федор. - Только теперь мы будем по-другому жить. Мы будем жить счастливо» (417).

Полную реализацию (кульминацию) утопическое начало получает в сценах с солнцем, которое нашим героям подарили 
ученые Института физики Солнца. Солнце - это и бытовой научно-фантастический прибор, освещающий и обогревающий жилище, и одновременно - символ утопии. Внешне это выглядит похожим на утопические аллюзии в «Приключениях Незнайки в Солнечном городе», но у Н. Носова, как мы уже отмечали, эти аллюзии замкнуты во взрослом плане содержания произведения, они сугубо рационалистичны, основаны на словесной перекличке и изображении социальной модели общества. У Э. Успенского «взрослое» и «детское» слиты воедино, поэтому символика оказывается бытовой, а быт - символичным, и апеллирует он не к взрослой рациональности, а к детской эмоциональности (которая может сохраняться в любом возрасте и входит в понятие «детскость» (см., напр.: $[3,111-114]))$. Когда включили солнце, «все в доме ожило. И цветы к солнцу потянулись, и бабочки откуда-то выбрались. И теленок Гаврюша стал скакать, как на лужайке.

А на дворе сырость, холод и слякоть. Скоро зима подойдет. Их домик с улицы так и светится, как игрушечный. <...>

С тех пор у них очень хорошая жизнь началась» (487).

Перед нами - утопия, причем детская. Не случайно свой подарок ученые сами (в прилагающейся записке) называют так: «солнце маленькое, домашнее (курсив мой. - A. С.)» (486). Это солнце и есть маленькая (детская) домашняя утопия.

Еще одна постоянная черта классической утопии - безгеройность - отсутствует в утопии детской. По словам T. А. Чернышевой, «в утопии речь идет не о судьбах отдельных героев (классическая утопия по сути дела безгеройна, ибо наблюдателя-путешественника, ведущего рассказ, трудно назвать таковым), а о судьбе социума в целом, об общих принципах организации жизни людей» $[6,307]$. Безгеройное повествование неинтересно читателю-ребенку, и в повести-сказке Э. Успенского именно судьбы (прошлое, настоящее и будущее) дяди Федора, пса и кота, их противостояние проискам почтальона Печкина захватывают внимание ребенка, и повествование об общих принципах жизни людей заменяется изображением, как мы уже отмечали, устойчивых, повседневных форм этой жизни. 
С безгеройностью связаны и описательность, и некоторая пассивность классической утопии. В какой-то мере это есть и у Э. Успенского, но в значительно меньшем объеме, чем во взрослой утопии. Дело в том, что в мире устойчивого быта (и бытия) катастрофических, серьезных изменений быть (как и во взрослой утопии) не может, но детское сознание на фоне этой устойчивости любую мелочь превращает в событие: «Посмотрите, что я нарисовал!» - обращается малыш к родителям, а потом долго радуется и всем рассказывает о своем успехе. Так и в сказочной повести Э. Успенского любая мелочь превращается в достойное большого внимания и интересное событие: и поведение Шарика во дворе, и их споры с котом Матроскиным, и доставка посылки и т. д. Так преодолевается пассивность утопии.

Любопытно отметить, что фантастическая литература (от И. Ефремова и братьев Стругацких до современных авторов), обращаясь к утопическому изображению будущего, неизменно ищет способы преодоления изначальной утопической пассивности. Так обстоит дело, скажем, в романе И. Ефремова «Туманность Андромеды», в котором «главы, относящиеся к разным планам (утопическому и приключенческому, связанному с космическим путешествием звездолета “Тантра”. A. C.), чередуются, и получается, что утопическая ткань повествования о будущем “прошивается” красной нитью динамичного сюжета: утопия “прошивается” сказкой» $[2,171]$.

В детской утопии Э. Успенского есть особенность, которая, как правило, отсутствует в утопии взрослой, ибо она носит не утопический, а фольклорно-сказочный характер. (Напомним, что именно на поэтику фольклорной волшебной сказки опирается сказка литературная.) Эту, «одну из основных черт внутреннего мира сказки», Д. С. Лихачев определяет так: «малое сопротивление в ней материальной среды, “сверхпроводимость” ее пространства» $[1,385]$.

В повести-сказке «Дядя Федор, пес и кот» пространство «сверхпроводимо». Д. С. Лихачев далее пишет: «В русской сказке сопротивление среды почти отсутствует. Герои передвигаются с необыкновенной скоростью <...> Препятствия, которые встречает герой по дороге, - только сюжетные, но 
не естественные, не природные. Физическая среда сказки сама по себе как бы не знает сопротивления. <..> Герой отправляется в путь и достигает цели без усталости, дорожных неудобств, болезни, случайных, не обусловленных сюжетом попутных встреч и т. д.» $[1,386]$.

В сказочной повести Э. Успенского это именно так. Открывающее действие путешествие дяди Федора в компании с котом, по сути дела, в неизвестность, случись оно в реальности, было бы и трудным, и тяжелым, много раз могло бы закончиться плачевно, и наверняка бы не привело их в сказочное Простоквашино.

Иногда совпадение с народной сказкой оказывается буквальным. Героям сказочной повести понадобилось купить корову (ведь коты любят молоко).

«- Надо бы, - соглашается дядя Федор. - Да где денег взять?» (411). Матроскин и Шарик тут же затевают спор - кого из них можно продать? Дядя Федор вмешивается: «- Никого мы продавать не будем. Мы пойдем клад искать. - Ура! кричит Шарик. - Давно пора!» (412).

Герои отправляются в лес, находят поляну, где «земля вон какая мягкая - один песок» (413) и выкапывают сундук. Приходят домой, смотрят - «очень много денег в сундуке. Не только корову - целое стадо можно купить вместе с быком. И они решили, что каждый себе подарок сделает. Что хочет, то и купит» (415). Герои у Э. Успенского поступают точь-в-точь как герои фольклорной волшебной сказки. Д. С. Лихачев пишет: «Деньги добываются в сказке не трудом, а случаем: кто-то указывает герою вырыть их из-под сырого дуба (Афанасьев, № 259)» [1, 387].

Стоит заметить, что в повести-сказке Э. Успенского «сверхпроводимость» обнаруживается не только в физической, но и в социальной среде (хотя бы потому, что характеристика устройства социума отсутствует).

И, наконец, еще одна особенность детской утопии Э. Успенского, которая в утопии взрослой факультативна: детская утопия не может существовать без игры, ибо «хорошее место» без игры в глазах ребенка-читателя не может быть «хорошим». Поэтому мы можем рассматривать утопический мир повести-сказки Э. Успенского как игровой мир, точнее, как мечту ребенка о таком мире. 
Это относится, прежде всего, к героям сказочной повести. Ее герои - дети. И они играют в самую интересную для ребенка игру - «во взрослых». Не случайно все обитатели утопического Простоквашино обладают детскими характерами, даже почтальон Печкин, представляющий известную в детской литературе (и в жизни) фигуру «злого соседского мальчишки», вредного и любопытного, ведь и главная мечта почтальона Печкина - сугубо детская. Он говорит маме и папе: «- Спасибо вам! Я почему нехороший был? Потому что у меня велосипеда не было. А теперь я сразу добреть начну. И какую-нибудь зверушку заведу, чтобы жить веселей: ты домой приходишь, а она тебе радуется!.. Приезжайте в наше Простоквашино!..» (499). Но взрослым нет доступа в детскую утопию (лишь маме и папе разрешено эпизодически и временно посещать ее). Взрослых нет, ибо в утопии, как мы отмечали, сами дети играют «во взрослых». Тема игры в повести Э. Успенского исключительно важна, а сама игра столь многогранна, что требует отдельного разговора.

\section{Примечания}

1 Успенский Э. Н. Дядя Федор, пес и кот // Успенский Э. Н. Крокодил Гена и его друзья. Повести. Сказки. М.: Эксмо, 2004. С. 407. Далее ссылки на это издание приводятся в тексте статьи с указанием номера страницы в круглых скобках.

\section{Список литературы}

1. Лихачев Д. С. Поэтика древнерусской литературы. - Л.: Худож. лит., 1971. - $414 \mathrm{c}$.

2. Неёлов Е. М. Волшебно-сказочные корни научной фантастики. - Л.: ЛГУ, 1986. - $200 \mathrm{c}$.

3. Рогачев В. А. «Память детства» как категория поэтики детской литературы // Проблемы детской литературы. - Петрозаводск: ПетрГУ, 1984. - C. 111-114.

4. Торшин А. А. Трилогия Н. Н. Носова о Незнайке: недетское содержание детской сказки // Мировая словесность для детей и о детях. - М., 2006. - Вып. 11. - С. 240-242.

5. Чаликова В. А. Предисловие // Утопия и утопическое мышление: антология зарубежной литературы. - М.: Прогресс, 1991. - С. 3-20.

6. Чернышева Т. А. Природа фантастики. - Иркутск: Изд-во Иркутского университета, 1984. - 336 c. 
Anna E. Strukova

Petrozavodsk State University

(Petrozavodsk, Russian Federation)

annaneyolova@yandex.ru

\title{
CHILDREN'S UTOPIA \\ (A Tale by E. Uspensky “Uncle Fyodor, \\ His Dog and His Cat")
}

\begin{abstract}
This article analyzes the specifics of the "children's" utopia based on E. Uspensky's tale "Uncle Fyodor, his Dog and his Cat", that represents a childhood dream of a good life, of the achievement of children's aspirations. The analysis is conducted in comparison with the specific features of the classic "adult" utopia. The folkloristic and fairy character of Uspensky's children's utopia is remarked here as well as the "superconductivity" of its space; the role of a game in the utopia; the lack of a common feature of any classic utopia which is the "absence of a hero". It is concluded among other things that social structure of a society, which plays the main role in the "adult" utopia, is substituted here for familiar to a child daily routines that organize existence. Special attention in the article is given to the episode with the Sun presented to the characters by the scientists of the Institute of Solar physics that is replete with the symbolic meaning. In E. Uspensky's tale "Uncle Fyodor, his Dog and his Cat" adult and children levels of meaning do not exist separately but interact and penetrate one into another.
\end{abstract}

Keywords: E. Uspensky, utopia, children's utopia, game, literary fairy tales, children's literature

\section{References}

1. Likhachev D. S. Poetika drevnerusskoy literatury [The Poetics of Old Russian Literature]. Leningrad, Khudozhestvennaya literatura Publ., 1971. 414 p.

2. Neyolov E. M. Volshebno-skazochnye korni nauchnoy fantastiki [Magical Fairy Tale Roots of Science Fiction]. Leningrad, Leningrad State University Publ., 1986. 200 p.

3. Rogachev V. A. «Pamyat' detstva» kak kategoriya poetiki detskoy literatury ["Memory of Childhood" as a Category of Poetics of Children's Literature]. Problemy detskoy literatury [The Problems of Children's Literature]. Petrozavodsk, Petrozavodsk State University Publ., 1984, pp. 111-114.

4. Torshin A. A. Trilogiya N. N. Nosova o Neznayke: nedetskoe soderzhanie detskoy skazki [Trilogy of N. N. Nosov about Neznayka: Unchildish Content of a Children's Tale]. Mirovaya slovesnost' dlya detey i o detyakh [World Literature for Children and about Children]. Moscow, 2006, issue 11, pp. 240-242.

5. Chalikova V. A. Predislovie [Introduction]. Utopiya i utopicheskoe myshlenie: antologiya zarubezhnoy literatury [Utopia and Utopian Thinking: Anthology of Foreign Literature]. Moscow, Progress Publ., 1991, pp. 3-20.

6. Chernysheva T. A. Priroda fantastiki [Nature of The Fantastika]. Irkutsk, Irkutsk State University Publ., 1984. 336 p.

Дата поступления в редакиию: 20.09.2015

(C) Струкова А. Е., 2016 